\title{
PENGARUH INKUIRI TERBIMBING, GAYA KOGNITIF, DAN MOTIVASI BERPRESTASI TERHADAP KETERAMPILAN PROSES SAINS SISWA KELAS V SD
}

\author{
I Wayan Ekayogi, Ni Wayan Rati
}

\author{
Jurusan Pendidikan Guru Sekolah Dasar, Fakultas Ilmu Pendidikan \\ Universitas Pendidikan Ganesha, Jln. Udayana No. 11 Singaraja \\ e-mail: ekayogi01@gmail.com
}

\begin{abstract}
This research aimed to determine the effect of guided inquiry learning model, cognitive style, and achievement motivation on science process skills in fifth grade elementary school in cluster III Tegallalang District . This research is classified as quasi experiment with the design of the post-test only control group design. The population of the research is a fifth grade students in Cluster III Elementary School Tegallalang District 2015/2016 school year totaling 123 people. Samples were students of fifth grade elementary school No 1 Sebatu, elementary school No 3 Sebatu and elementary school No 5 Sebatu selected by simple random sampling technique. The research instrument was a test of cognitive style (MFFT), test science process skills and achievement motivation questionnaire. Data were analyzed using descriptive statistics, Anacova two lanes and the product moment correlation. The results showed (1) there are significant differences between the groups science process skills of students that learned with guided inquiry learning model and student groups that learned with conventional learning models after controlling for achievement motivation $\left(\mathrm{F}_{\text {count }}=54,714\right.$ with sig. $\left.=0,000\right)$. (2) There are significant differences between the groups science process skills of students who have cognitive style reflective and groups of students who have cognitive style after controlling impulsive achievement motivation $\left(\mathrm{F}_{\text {count }}=70,349\right.$ with sig. $\left.=0,000\right)$. (3) There is a significant interaction between guided inquiry learning model and cognitive styles of students to the science process skills after controlling for achievement motivation $\left(\mathrm{F}_{\text {count }}=4,400\right.$ with sig. $=$ $0,039)$. (4) There is a significant correlation between achievement motivation and science process skills $\left(r_{\text {count }}=0,427\right.$ with sig. $\left.=0.000\right)$.
\end{abstract}

Keywords: guided inquiry, cognitive style, science process skills, achievement motivation

\begin{abstract}
ABSTRAK: Penelitian ini bertujuan untuk mengetahui pengaruh model pembelajaran inkuiri terbimbing, gaya kognitif, dan motivasi berprestasi terhadap keterampilan proses sains pada siswa kelas V SD di gugus III Kecamatan Tegallalang. Penelitian ini tergolong quasi experiment dengan rancangan the post-test only control group design. Populasi penelitian adalah siswa kelas V SD Negeri di Gugus III Kecamatan Tegallalang tahun pelajaran 2015/2016 yang berjumlah 123 orang. Sampel penelitian adalah siswa kelas V SDN 1 Sebatu, SDN 3 Sebatu, dan SDN 5 Sebatu yang dipilih dengan teknik simple random sampling. Instrumen penelitian adalah tes gaya kognitif (MFFT), tes keterampilan proses sains dan kuesioner motivasi berprestasi. Data dianalisis menggunakan statistik deskriptif, ANAKOVA dua jalur dan korelasi product moment. Hasil penelitian menunjukkan (1) terdapat perbedaan yang signifikan keterampilan proses sains antara kelompok siswa yang dibelajarkan dengan model pembelajaran inkuiri terbimbing dan kelompok siswa yang dibelajarkan dengan model pembelajaran konvensional setelah mengontrol motivasi berprestasi $\left(F_{\text {hitung }}=54,714\right.$ dengan sig. $=0,000)$. (2) Terdapat perbedaan yang signifikan keterampilan proses sains antara kelompok siswa yang memiliki gaya kognitif reflektif dan kelompok siswa yang memiliki gaya kognitif impulsif setelah mengontrol motivasi berprestasi $\left(\mathrm{F}_{\text {hitung }}=70,349\right.$ dengan $\operatorname{sig}$. $=$ 0,000). (3) Terdapat interaksi yang signifikan antara model pembelajaran inkuiri terbimbing
\end{abstract}


dan gaya kognitif siswa terhadap keterampilan proses sains setelah mengontrol motivasi berprestasi $\left(\mathrm{F}_{\text {hitung }}=4,400\right.$ dengan sig. $\left.=0,039\right)$. (4) Terdapat korelasi yang signifikan antara motivasi berprestasi dengan keterampilan proses sains $\left(\mathrm{r}_{\mathrm{hitung}}=0,427\right.$ dengan sig. $=0,000$ ).

Kata-kata kunci: inkuiri terbimbing, gaya kognitif, keterampilan proses sains, motivasi berprestasi

Pendidikan merupakan hal yang sangat penting bagi manusia. Hal ini dikarenakan pendidikan tidak pernah terlepas dari kehidupan manusia. Di samping itu, hampir semua manusia memperoleh dan melaksanakan pendidikan dalam kehidupannya sehari-hari. Manusia senantiasa dihadapkan dengan berbagai situasi dan kondisi yang berkaitan dengan pendidikan. Salah satu contohnya adalah anak-anak menerima pendidikan dari orang tuanya kemudian ketika mereka sudah dewasa dan berkeluarga mereka akan mendidik anakanaknya sehingga akan terbentuk kepribadian yang baik.

Pendidikan pada hakekatnya merupakan suatu proses pemanusiaan manusia. Proses pemanusiaan tersebut dilakukan melalui pendidikan formal, infomal dan nonformal. Melalui aktivitas pendidikan itulah, pertumbuhan, perkembangan, pembentukan kepribadian, dan kemampuan serta itelektual seseorang akan terbentuk (Dantes, 2014).

Dalam proses pembangunan, pendidikan menempati posisi sentral. Hal ini dikarenakan pendidikan berkaitan dengan proses pencetakan sumber daya manusia (SDM) yang berkualitas. Hal senada juga diungkapkan oleh Hamalik (2012) yang menyatakan bahwa pendidikan merupakan bagian integral dalam pembangunan sehingga pendidikan tidak dapat dipisahkan dari proses pendidikan itu sendiri karena pendidikan merupakan hal yang sangat penting untuk kemajuan bangsa ini. Kemajuan bangsa akan dapat tercapai apabila memiliki suatu output atau SDM yang berkualitas.

Berbagai upaya telah dilakukan pemerintah untuk meningkatkan kualitas pendidikan di Indonesia sehingga menghasilkan output yang berkualitas. Salah satu upaya yang dilakukan pemerintah untuk meningkatkan kualitas pendidikan di Indonesia adalah dengan memperbarui secara berkala kurikulum yang berlaku di Indonesia. Selain pembaruan kurikulum secara berkala pemerintah juga melakukan upaya yang lain, yaitu dengan menyalurkan bantuan berupa Dana Bantuan Operasional Sekolah (BOS) ke sekolah-sekolah. Upaya lain yang dilakukan pemerintah untuk meningkatkan kualitas pendidikan di Indonesia adalah dengan memberikan beasiswa kepada para siswa-siswa yang berprestasi dan siswa-siswa yang kurang mampu. Kenyataan di lapangan, masih terdapat kesenjangan antara hasil yang diharapakan pemerintah dengan hasil yang diperoleh selama ini.

Salah satu bukti adanya kesenjangan tersebut adalah laporan UNESCO dalam Education For All Global Monitoring Report (EFA-GMR), Indeks Pembangunan Pendidikan Untuk Semua atau The Education for All Development Index (EDI) Indonesia tahun 2014. Pada tahun 2014 Indonesia berada pada peringkat 57 dari 115 negara. Hal tersebut mencerminkan pencapaian kualitas pendidikan di Indonesia belum optimal (Kemenkopmk, 2015 ).

Salah satu mata pelajaran yang ikut mempengaruhi perkembangan kualitas pendidikan adalah Ilmu Pengetahuan Alam (IPA). IPA memberikan kontribusi yang cukup besar terhadap perkembangan teknologi dalam berbagai sektor kehidupan di masyarakat. Hal ini dikarenakan sains (IPA) dan teknologi berkaitan sangat erat dimana produk sains diterapkan dalam teknologi. Sains memberi cara atau alat untuk mengestimasi perilaku benda-benda (material). Sebaliknya teknologi memberikan dukungan untuk kemajuan sains (Suastra, 2009). Dengan demikian, penguasaan terhadap IPA perlu terus ditingkatkan sehingga mampu bersaing dengan bangsa-bangsa lain di era globalisasi sekarang ini. Pembelajaran IPA harus mampu menciptakan kondisi yang memberikan peluang kepada pelajar untuk mengembangkan kemampuan berpikir kritis, kreatif, produktif dan inovatif secara optimal untuk memperoleh pengetahuan secara mandiri 
melalui proses ilmiah. Namun, kenyataan di lapangan masih ditemukan berbagai permasalahan dalam proses pembelajaran IPA sehingga siswa tidak mempunyai kesempatan untuk mengembangkan kemampuannya secara optimal.

Dalam proses pembelajaran, setiap siswa memiliki karakteristik yang berbedabeda khususnya gaya kognitif yang dimiliki siswa. Perbedaan gaya kognitif pada siswa akan menyebabkan perbedaan hasil belajar yang diperoleh siswa. Hasil belajar yang diperoleh siswa tidak hanya berupa angkaangka saja, melainkan juga berupa keterampilan-keterampilan. Salah satu keterampilan yang diperoleh siswa dalam proses pembelajaran adalah keterampilan proses. Keterampilan-keterampilan inilah yang disebut sebagai keterampilan proses IPA atau keterampilan proses sains (Suatra, 2009).

Salah satu yang seharusnya menjadi prioritas dalam proses pembelajaran IPA adalah guru harus sering menerapkan model pembelajaran inovatif khususnya model pembelajaran inkuiri terbimbing dalam proses pembelajaran. Hal ini dikarenakan model pembelajaran inkuiri terbimbing memiliki kelebihan sehingga dapat meningkatkan keterampilan proses sains siswa. Kurniasih \& Berlin (2015) menyatakan kelebihan model pembelajaran inkuiri terbimbing adalah model pembelajaran inkuiri memberikan ruang kepada siswa untuk belajar sesuai dengan gaya kognitif mereka, model pembelajaran inkuiri dapat melayani kebutuhan siswa yang memiliki kemampuan di atas rata-rata, model pembelajaran inkuiri dianggap sesuai dengan perkembangan psikologi modern yang menganggap belajar adalah proses perubahan, model pembelajaran inkuiri dapat menciptakan pembelajaran yang bermakna karena mengembangkan aspek kognitif, afektif dan psikomotor secara seimbang.

Pembelajaran inkuiri terbimbing menekankan pada proses penemuan oleh siswa sendiri seperti dikemukakan Massialas (dalam Matthew \& Igharo, 2013:136) yang menyatakan bahwa pembelajaran inkuiri terbimbing sebagai, "The guided inquiry is a teaching method that enables students to move step-by step from the identification of a problem defining the problem formulation hypothesis, collection of data, verification of results, and generalization to the drawing of conclusion". Pembelajaran inkuiri terbimbing dapat diartikan sebagai metode mengajar yang memungkinkan siswa untuk bergerak selangkah demi selangkah dari identifikasi masalah, mendefinisikan hipotesis, perumusan masalah, pengumpulan data, verifikasi hasil, dan generalisasi ke gambar menuju kesimpulan.

Selain menerapkan model pembelajaran yang inovatif, guru perlu mendesain pembelajaran yang sesuai dengan karakteristik siswa khusunya gaya kognitif yang dimiliki siswa. Hayes \& Allinson (dalam Khodadady et al., 2012:806) menyatakan bahwa, "Related to the manner in which people interact with their environment, organize and interpret what they understand from the interaction and employ their interpretations to take appropriate actions". Dalam hal ini gaya kognitif diartikan berkaitan dengan cara dimana orang berinteraksi dengan lingkungannya, mengatur dan menafsirkan apa yang mereka pahami dari interaksi dan menggunakan interpretasi mereka untuk mengambil tindakan yang tepat. Oleh karena hal tersebut, proses pembelajaran yang sesuai dengan karakteristik siswa sangat diperlukan.

Dalam pelaksanaan proses pembelajaran, guru juga perlu meningkatkan keterampilan proses sains siswa. Hal ini dikarenakan keterampilan proses merupakan keterampilan yang mengarah kepada pembangunan kemampuan mental, fisik, dan sosial yang mendasar sebagai penggerak kemampuan yang lebih tinggi dalam diri individu siswa (Usman \& Setiawati dalam Susanto, 2013).

Selain itu, dalam proses pembelajaran guru perlu memperhatikan motivasi berprestasi yang dimiliki oleh siswa. Hal ini dikarenakan, dalam proses pembelajaran setiap siswa memiliki motivasi berprestasi yang berbedabeda. McClelland (dalam Suarni, 2004) menyatakan bahwa motivasi berprestasi adalah hasrat atau keinginan untuk melakukan segala sesuatu dengan sebaik-baiknya bukan ditujukan untuk memperoleh penghargaan sosial atau prestasi melainkan untuk memperoleh kepuasan batin dalam dirinya. Keinginan yang berbeda-beda dalam melakukan sesuatu akan dapat menyebabkan perbedaan hasil yang diperoleh siswa. Oleh karenanya, motivasi berprestasi yang dimiliki siswa harus diperhatikan agar hasil yang 
diperoleh siswa tidak jauh berbeda antara siswa yang satu dengan siswa yang lainnya.

Tujuan penelitian ini adalah: (1) menganalisis perbedaan yang signifikan keterampilan proses sains antara kelompok siswa yang dibelajarkan dengan model pembelajaran inkuiri terbimbing dan kelompok siswa yang dibelajarkan dengan pembelajaran konvensional setelah mengontrol motivasi berprestasi pada siswa kelas V SD di Gugus III Kecamatan Tegallalang tahun pelajaran 2015/2016. (2) Menganalisis perbedaan yang signifikan keterampilan proses sains antara kelompok siswa yang memiliki gaya kognitif reflektif dan kelompok siswa yang memiliki gaya kognitif impulsif setelah mengontrol motivasi berprestasi pada siswa kelas V SD di Gugus III Kecamatan Tegallalang tahun pelajaran 2015/2016. (3) Menganalisis interaksi yang signifikan antara model pembelajaran inkuiri terbimbing dan gaya kognitif siswa terhadap keterampilan proses sains setelah mengontrol motivasi berprestasi pada siswa kelas V SD di Gugus III Kecamatan Tegallalang tahun pelajaran 2015/2016. (4) Menganalisis korelasi yang signifikan antara motivasi berprestasi dengan keterampilan proses sains pada siswa kelas $\mathrm{V}$ SD di Gugus III Kecamatan Tegallalang tahun pelajaran 2015/2016.

\section{METODE}

Jenis penelitian ini adalah penelitian eksperimen semu (quasi exsperiment). dengan rancangan Post-Test Only Control Group design. Populasi dalam penelitian adalah seluruh siswa kelas V di SD Gugus III Kecamatan Tegallalang tahun pelajaran 2015/2016 yang berjumlah 123 orang siswa. Sampel yang digunakan telah diuji kesetaraannya. Sampel penelitian adalah siswa kelas V SDN 1 Sebatu, SDN 3 Sebatu, dan SDN 5 Sebatu yang dipilih dengan teknik simple random sampling.

Seluruh siswa dalam kelas yang menjadi sampel diberikan tes gaya kognitif dan kuesioner motivasi berprestasi. Namun, dalam penelitian ini tidak semua data siswa dianalisis. Data yang dianalisis adalah data yang berasal dari siswa yang memilki gaya kognitif reflektif (B1), dan gaya kognitif impulsif (B2). Sedangkan data siswa yang tidak termasuk ke dalam gaya kognitif reflektif (B1) dan gaya kognitif impulsif (B2) tidak dimasukan ke dalam data yang dianalisis.

Penelitian ini melibatkan empat variabel, yaitu satu variabel bebas, satu variabel moderator, satu kovariabel, dan satu variabel terikat. Variabel bebas dalam penelitian ini adalah model pembelajaran (A) yang terdiri dari dua, yaitu: (1) model pembelajatan inkuiri terbimbing (A1), dan pembelajaran konvensional (A2). Variabel moderator dalam penelitian ini adalah gaya kognitif (B) yang terdiri dari dua, yaitu: (1) gaya kognitif reflektif (B1), dan gaya kognitif impulsif (B2). Kovariabel dalam penelitian ini adalah motivasi berprestasi siswa (X). Dan variabel terikat dalam penelitian ini adalah keterampilan proses sains siswa (Y). Dengan demikian desain analisisnya yang digunakan adalah ANAKOVA dua jalur dengan satu kovariabel.

Pengumpulan data gaya kognitif siswa digunakan tes gaya kognitif (MFFT), data keterampilan proses sains siswa dikumpulkan dengan tes keterampilan proses sains dan data motivasi berprestasi dikumpulkan dengan menyebarkan kuesioner pada siswa. Uji coba istrumen hanya dilakukan pada tes keterampilan proses sains dan kuesioner motivasi berprestasi. Tes gaya kognitif (MFFT) tidak diuji coba karena tes gaya kogntif (MFFT) yang digunakan merupakan tes yang sudah standar dan dan telah memenuhi kriteria untuk digunakan sebagai instrumen penelitian. Uji coba tes keterampilan proses sains meliputi validitas isi, validitas butir, reliabilitas tes, daya beda butir tes dan tingkat kesukaran butir tes. Sedangkan uji coba kuesioner motivasi berprestasi meliputi validitas isi, validitas butir, dan reliabilitas.

Analisis data dalam penelitian ini dilakukan dalam tiga tahap. Pada tahap pertama dilakukan analisis deskriptif. Pada tahap kedua dilakukan uji prasyarat untuk pembuktian persyaratan analisis statistik, yang terdiri dari uji normalitas sebaran data, uji homogenitas varians antar kelompok dan uji linearitas data. Sedangkan pada tahap ketiga dilakukan analisis untuk pembuktian hipotesis.

Pengujian terhadap hipotesis penelitian dilakukan melalui metode statistika. Pengujian hipotesis pertama, kedua, dan ketiga digunakan formula statistik ANAKOVA dua dua jalur dengan satu kovariabel. Sedangkan pengujian hipotesis keempat digunakaan teknik korelasi 
product moment. Sebelum dilakukan uji hipotesis dengan metode statistika tersebut, terlebih dahulu dilakukan uji prasyarat analisis yang telah ditentukan. Seluruh pengujian yang dilakukan menggunakan bantuan program SPSS versi 17 for windows.

\section{HASIL DAN PEMBAHASAN}

Hasil perhitungan analisis deskriptif
menunjukkan bahwa rata-rata skor keterampilan proses sains yang diperoleh oleh kelompok siswa yang dibelajarkan dengan model pembelajaran inkuiri terbimbing $\left(\mathrm{A}_{1} \mathrm{Y}\right)$ adalah 45,15 dan rata-rata skor keterampilan proses sains yang diperoleh oleh kelompok siswa yang dibelajarkan dengan pembelajaran konvensional $\left(\mathrm{A}_{2} \mathrm{Y}\right)$ adalah 34,08. Dengan demikian, keterampilan proses sains siswa yang dibelajarkan dengan model pembelajaran inkuri terbimbing $\left(\mathrm{A}_{1} \mathrm{Y}\right)$ lebih baik dibandingkan dengan siswa yang dibelajarkan dengan pembelajaran konvensional $\left(\mathrm{A}_{2} \mathrm{Y}\right)$.

Selanjutnya, secara keseluruhan rata-rata skor keterampilan proses sains yang diperoleh oleh kelompok siswa yang memiliki gaya kognitif reflektif $\left(\mathrm{B}_{1} \mathrm{Y}\right)$ adalah 46,48 dan ratarata skor keterampilan proses sains yang diperoleh oleh kelompok siswa yang memiliki gaya kognitif impultsif $\left(\mathrm{B}_{2} \mathrm{Y}\right)$ adalah 32,75. Dengan demikian, keterampilan proses sains siswa yang memiliki gaya kognitif reflektif $\left(\mathrm{B}_{1} \mathrm{Y}\right)$ lebih baik dibandingkan dengan siswa yang memiliki gaya kognitif impultsif $\left(\mathrm{B}_{2} \mathrm{Y}\right)$.

Selain itu, hasil perhitungan analisis deskriptif menunjukkan bahwa rata-rata skor keterampilan proses sains yang diperoleh oleh kelompok siswa bergaya kognitif reflektif yang dibelajarkan dengan model pembelajaran inkuiri terbimbing $\left(\mathrm{A}_{1} \mathrm{~B}_{1} \mathrm{Y}\right)$ adalah 50,85 dan rata-rata skor keterampilan proses sains yang diperoleh oleh kelompok siswa bergaya kognitif impulsif yang dibelajarkan dengan model pembelajaran inkuiri terbimbing $\left(\mathrm{A}_{1} \mathrm{~B}_{2} \mathrm{Y}\right)$ adalah 39,45. Sedangkan rata-rata skor keterampilan proses sains yang diperoleh oleh kelompok siswa bergaya kognitif reflektif yang dibelajarkan dengan pembelajaran konvensional $\left(\mathrm{A}_{2} \mathrm{~B}_{1} \mathrm{Y}\right)$ adalah 42,10 dan ratarata skor keterampilan proses sains yang diperoleh oleh kelompok siswa bergaya kognitif impulsif yang dibelajarkan dengan pembelajaran konvensional $\left(\mathrm{A}_{2} \mathrm{~B}_{2} \mathrm{Y}\right)$ adalah 26,05 .

Pengujian hipotesis pertama, kedua dan ketiga digunakan teknik ANAKOVA dua jalur dengan satu kovariabel dan pengujian hipotesis keempat digunakan teknik dan korelasi product moment. Adapun ringkasan hasil pengujian dengan teknik ANAKOVA dua jalur dengan satu kovariabel tersaji pada Tabel 1.

Tabel 1. Ringkasan Hasil Uji Anakova Dua Jalur dengan Satu Kovariabel

\begin{tabular}{crrrrcc}
\hline Sumber Varian & \multicolumn{1}{c}{$\mathrm{JK}$} & $\mathrm{db}$ & \multicolumn{1}{c}{$\mathrm{RJK}$} & $\mathrm{F}_{\text {hitung }}$ & $\begin{array}{c}\mathrm{F}_{\text {tabel }} \\
(\alpha=0,05)\end{array}$ & Keterangan \\
\hline $\mathrm{X}$ & 307,098 & 1 & 307,098 & 7,912 & 3,96 & Signifikan \\
$\mathrm{A}$ & 2123,873 & 1 & 2123,873 & 54,717 & 3,96 & Signifikan \\
$\mathrm{B}$ & 2730,635 & 1 & 2730,635 & 70,349 & 3,96 & Signifikan \\
Inter AB & 170,787 & 1 & 170,787 & 4,400 & 3,96 & Signifikan \\
dalam & 2911,152 & 75 & 38,815 & - & - & \\
Total & 9546,988 & 79 & - & - & - & \\
\hline
\end{tabular}

Berdasarkan hasil uji hipotesis yang telah dilakukan dapat dijabarkan hasil uji hipotesis dalam penelitian ini sebagai berikut: Pertama, setelah motivasi berprestasi dikontrol diperoleh nilai $\mathrm{F}_{\text {hitung }}=54,717$ dengan nilai sig. $=0,000$. Hal ini berarti nilai sig. yang diperoleh lebih kecil dari 0,05 sehingga nilai $F_{\text {hitung }}$ yang diperoleh signifikan, yang berarti $\mathrm{H}_{1}$ diterima. Selanjutnya, terbukti bahwa besaran rata-rata skor keterampilan proses sains kelompok siswa yang dibelajarkan dengan model pembelajaran inkuIri terbimbing, yaitu 45,15 yang lebih besar daripada besaran rata-rata skor keterampilan proses sains kelompok siswa yang dibelajarakan dengan pembelajaran konvensional sebesar 34,08.

Dengan demikian dapat disimpulkan bahwa terdapat perbedaan yang signifikan keterampilan proses sains antara kelompok 
siswa yang dibelajarkan dengan model pembelajaran inkuiri terbimbing dan kelompok siswa yang dibelajarkan dengan model pembelajaran konvensional setelah mengontrol motivasi berprestasi pada siswa kelas V SD di Gugus III Kecamatan Tegallalang tahun pelajaran 2015/2016.

Hasil uji hipotesis tersebut menunjukkan bahwa model pembelajaran inkuiri terbimbing lebih unggul dalam meningkatkan keterampilan proses sains siswa daripada model pembelajaran konvensional. Hal ini dikarenakan model inkuiri terbimbing mempunyai kelebihan-kelebihan. Kurniasih \& Berlin (2015) menyatakan kelebihan model pembelajaran inkuiri adalah model pembelajaran inkuiri memberikan ruang kepada siswa untuk belajar sesuai dengan gaya kognitif yang dimiliki, model pembelajaran inkuiri dapat melayani kebutuhan siswa yang memiliki kemampuan di atas rata-rata sehingga siswa yang mempunyai kecepatan belajar yang bagus tidak akan terhambat oleh siswa yang lambat dalam belajar, model pembelajaran inkuiri dianggap sesuai dengan perkembangan psikologi modern yang menganggap belajar adalah proses perubahan, model pembelajaran inkuiri dapat menciptakan pembelajaran yang bermakna karena mengembangkan aspek kognitif, afektif dan psikomotor secara seimbang.

Hal ini juga dibuktikan dengan hasil penelitian Ergul et al. (2011) yang menemukan bahwa penggunaan model pembelajaran inkuiri terbimbing secara signifikan meningkatkan keterampilan proses sains siswa, dimana siswa dalam kelompok eksperimen memiliki kinerja yang lebih baik daripada siswa dalam kelompok kontrol. Demikian pula hasil penelitian yang dilakukan oleh Pandaeyani (2012) menemukan bahwa terjadi peningkatan persentase rata-rata keterampilan proses IPA siswa kelas V setelah dibelajarkan dengan menggunakan model pembelajaran inkuiri terbimbing. Hasil uji hipotesis juga menunjukkan bahwa secara umum, pembelajaran konvensional tidak banyak memberikan efek positif bagi peningkatan keterampilan proses sains pada siswa kelas V SDN di Gugus III Kecamatan Tegallalang tahun pelajaran 2015/2016. Hal ini dikarenakan, pembelajaran konvensional merupakan pembelajaran yang berpusat pada guru sehingga siswa tidak mempunyai keleluasaan menggunakan secara optimal kemampuan yang dimiliki dalam proses pembelajaran untuk menemukan suatu pengetahuan umum atau konsep yang diharapkan. Hal ini akan menyebabkan siswa bersifat pasif dalam mengikuti proses pembelajaran.

Berdasarkan paparan di atas, tampak jelas bahwa model pembelajaran inkuiri terbimbing lebih baik diterapkan untuk siswa daripada model pembelajaran konvensional karena model pembelajaran inkuiri terbimbing memberikan keleluasaan kepada siswa untuk menggunakan secara optimal kemampuan yang dimiliki dalam proses pembelajaran yang disertai dengan bimbingan guru sehingga siswa dapat menemukan pengetahuan umum atau konsep yang diharapkan.

Kedua, setelah motivasi berprestasi dikontrol diperoleh nilai $\mathrm{F}_{\text {hitung }}=70,349$ dengan nilai sig. $=0,000$. Hal ini berarti nilai sig. yang diperoleh lebih kecil dari 0,05 sehingga nilai $\mathrm{F}_{\text {hitung }}$ yang diperoleh signifikan, yang berarti $\mathrm{H}_{1}$ diterima.

Besaran skor rata-rata keterampilan proses sains siswa yang memiliki gaya kognitif reflektif pada kelompok eksperimen adalah 50,85 dan pada kelompok kontrol adalah 42,10 . Besaran skor rata-rata keterampilan proses sains siswa yang memiliki gaya kognitif impulsif pada kelompok eksperimen adalah 39,45 dan pada kelompok kontrol adalah 26,06. Hasil tersebut menunjukkan bahwa, secara keseluruhan terdapat perbedaan keterampilan proses sains antara kelompok siswa yang memiliki gaya kognitif reflektif dan kelompok siswa yang memiliki gaya kognitif impulsif setelah mengontrol motivasi berprestasi siswa.

Dengan demikian dapat disimpulkan bahwa terdapat perbedaan yang signifikan keterampilan proses sains antara kelompok siswa yang memiliki gaya kognitif reflektif dan kelompok siswa yang memiliki gaya kognitif impulsif setelah mengontrol motivasi berprestasi pada siswa kelas V SD di Gugus III Kecamatan Tegallalang tahun pelajaran 2015/2016.

Hasil tersebut menunjukkan bahwa, dengan mengontrol kovariabel motivasi berprestasi, terdapat perbedaan yang signifikan keterampilan proses sains antara kelompok siswa yang memiliki gaya kognitif reflektif dan kelompok siswa yang memiliki gaya 
kognitif impulsif. Perbedaan keterampilan proses sains antara kelompok siswa yang memiliki gaya kognitif reflektif dan kelompok siswa yang memiliki gaya kognitif impulsif juga dapat dilihat dari besaran skor rata-rata keterampilan proses sains siswa. Berdasarkan besaran skor rata-rata keterampilan proses sains siswa, dapat diketahui bahwa siswa yang memiliki gaya kognitif reflektif memilki besaran skor rata-rata lebih besar dibandingkan siswa yang memilki gaya kognitif impulsif.

Hal senada juga diungkapkan oleh Widadah (2013) yang menyatakan siswa yang reflektif adalah siswa yang mempunyai karakteristik lambat dalam menjawab soal, tetapi cermat sehingga jawaban cenderung benar. Sedangkan siswa yang impulsif adalah siswa yang mempunyai karakteristik cepat dalam menyelesaikan soal, tetapi kurang cermat sehingga jawaban cenderung salah.

Berdasarkan paparan di atas, tampak jelas bahwa keterampilan proses sains siswa yang memiliki gaya kognitif reflektif lebih baik dibanding siswa yang memilki gaya kognitif impulsif.

Ketiga, setelah motivasi berprestasi dikontrol diperoleh nilai $\mathrm{F}_{\text {hitung }}=4,400$ dengan nilai sig. $=0,039$. Hal ini berarti nilai sig. yang diperoleh lebih kecil dari 0,05 sehingga nilai $F_{\text {hitung }}$ yang diperoleh signifikan, yang berarti $\mathrm{H}_{1}$ diterima.

Interaksi antara model pembelajaran dengan gaya kognitif dapat dilihat juga dari skor rata-rata keterampilan proses sains yang dihasilkan. Siswa yang memilki gaya kognitif reflektif yang dibelajarkan dengan model inkuiri terbimbing menghasilkan rata-rata skor yang sangat tinggi, yaitu sebesar 50,85. Sedangkan siswa yang memilki gaya kognitif impulsif yang dibelajarkan dengan model inkuiri terbimbing menghasilkan rata-rata skor sebesar 39,45. Siswa yang memilki gaya kognitif reflektif yang dibelajarkan dengan pembelajaran konvensional menghasilkan ratarata skor, yaitu sebesar 42,10. Sedangkan siswa yang memilki gaya kognitif impulsif yang dibelajarkan dengan pembelajaran konvensional menghasilkan rata-rata skor sebesar 26,05. Berdasarkan hal tersebut, dapat diketahui bahwa siswa yang memilki gaya kognitif reflektif dan dibelajarkan dengan model pembelajaran inkuiri terbimbing mempunyai rata-rata skor keterampilan proses sains yang paling tinggi.
Dengan demikian dapat disimpulkan bahwa terdapat interaksi yang signifikan antara model pembelajaran inkuiri terbimbing dan gaya kognitif siswa terhadap keterampilan proses sains setelah mengontrol motivasi berprestasi pada siswa kelas V SD di Gugus III Kecamatan Tegallalang tahun pelajaran 2015/2016.

Massialas (dalam Matthew \& Igharo, 2013:136) menyatakan bahwa pembelajaran dengan model inkuiri terbimbing dapat diartikan sebagai metode mengajar yang memungkinkan siswa untuk bergerak selangkah demi selangkah dari identifikasi masalah, mendefinisikan hipotesis, perumusan masalah, pengumpulan data, verifikasi hasil, dan generalisasi ke gambar menuju kesimpulan.

Hayes \& Allinson (dalam Khodadady et al., 2012:806) menyatakan bahwa gaya kognitif diartikan sebagai cara dimana orang berinteraksi dengan lingkungannya, mengatur dan menafsirkan apa yang mereka pahami dari interaksi dan mempekerjakan interpretasi mereka untuk mengambil tindakan yang tepat. Ostlund (dalam Ergul et al., 2011:49) mendefinisikan keterampilan proses sains sebagai keterampilan memindahtangankan banyak ilmu dan mencerminkan suatu perilaku.

Berdasarkan paparan di atas, tampak jelas bahwa terdapat interaksi yang signifikan antara model pembelajaran inkuiri terbimbing dan gaya kognitif siswa terhadap keterampilan proses sains setelah mengontrol motivasi berprestasi siswa. Hal ini dikarenakan dengan model pembelajaran inkuiri terbimbing, siswa dapat belajar sesuai dengan gaya kognitif yang dimiliki sehingga siswa dapat meningkatkan keterampilan proses sains dalam proses pembelajaran.

Keempat. Hasil perhitungan menunjukkan nilai $r_{\text {hitung }}=0,427$ dengan nilai sig. $=0,000$. Hal ini berarti nilai sig. yang diperoleh lebih kecil dari 0,05 sehingga nilai $\mathrm{r}_{\text {hitung }}$ yang diperoleh signifikan, yang berarti $\mathrm{H}_{1}$ diterima.

Dengan demikian dapat disimpulkan bahwa terdapat korelasi yang signifikan antara motivasi berprestasi dengan keterampilan proses sains pada siswa kelas V SD di Gugus III Kecamatan Tegallalang tahun pelajaran 2015/2016. 
McClelland (dalam Suarni, 2004) menyatakan bahwa motivasi berprestasi adalah hasrat atau keinginan untuk melakukan segala sesuatu dengan sebaik-baiknya bukan ditujukan untuk memperoleh penghargaan sosial atau prestasi melainkan untuk memperoleh kepuasan batin dalam dirinya. Lebih lanjut Suarni (2004) menyatakan bahwa motivasi berprestasi adalah suatu konstruk psikologis yang berhubungan dengan usaha bagaimana melakukan sesuatu dengan sebaikbaiknya atas dasar kompetisi yang sehat dan bertanggung jawab untuk mencapai hasil yang maksimal berdasarkan atas ukuran keunggulan. Dengan demikian, motivasi berprestasi siswa adalah dorongan yang berasal dari dalam diri siswa dan dapat menyebabkan siswa melakukan sesuatu guna mencapai prestasi yang diharapkan dengan baik.

Keterampilan proses sains sangat penting untuk dilatihkan pada siswa sekolah dasar sehingga siswa akan terampil untuk menemukan sendiri pengetahuan atau konsep yang diharapkan dalam proses pembelajaran. Suastra (2009) mengemukakan keterampilan proses sains yang perlu dikembangkan adalah mengamati, menafsirkan, meramalkan, menggunakan alat dan bahan, menerapkan konsep, merencanakan kegiatan, berkomunikasi, dan bertanya.

Keterampilan proses sains adalah gabungan dari berpikir kritis dan penyelidikan dalam bidang keilmuan. Oleh karena itu, apabila siswa memiliki motivasi berprestasi yang tinggi untuk berpikir kritis melakukan pengamatan dan penyelidikan dalam bidang keilmuan, akan menyebabkan siswa memiliki keterampilan proses sains yang tinggi. Sebaliknya, apabila siswa memiliki motivasi berprestasi yang rendah untuk berpikir kritis melakukan pengamatan dan penyelidikan dalam bidang keilmuan, akan menyebabkan keterampilan proses sains siswa rendah. Temuan dalam penelitian ini sejalan dengan penelitian yang dilakukan Emmanuel et al. (2014) menemukan ada hubungan positif antara motivasi berprestasi dan prestasi akademik siswa.

Berdasarkan paparan di atas, tampak jelas bahwa terdapat korelasi yang signifikan antara motivasi berprestasi dengan keterampilan proses sains siswa. Hal ini karena dorongan yang berasal dari dalam diri siswa dan dapat menyebabkan siswa melakukan sesuatu guna mencapai prestasi yang diharapkan dengan baik.

\section{SIMPULAN}

Berdasarkan hasil penelitian dan pembahasan dapat disimpulkan bahwa (1) terdapat perbedaan yang signifikan keterampilan proses sains antara kelompok siswa yang dibelajarkan dengan model pembelajaran inkuiri terbimbing dan kelompok siswa yang dibelajarkan dengan pembelajaran konvensional setelah mengontrol motivasi berprestasi pada siswa kelas V SD di Gugus III Kecamatan Tegallalang tahun pelajaran $2015 / 2016\left(F_{\text {hitung }}=54,714\right.$ dengan sig. $=$ $0,000)$. (2) Terdapat perbedaan yang signifikan keterampilan proses sains antara kelompok siswa yang memiliki gaya kognitif reflektif dan kelompok siswa yang memiliki gaya kognitif impulsif setelah mengontrol motivasi berprestasi pada siswa kelas V SD di Gugus III Kecamatan Tegallalang tahun pelajaran 2015/2016 $\left(F_{\text {hitung }}=70,349\right.$ dengan sig. $=$ 0,000). (3) Terdapat interaksi yang signifikan antara model pembelajaran inkuiri terbimbing dan gaya kognitif siswa terhadap keterampilan proses sains setelah mengontrol motivasi berprestasi pada siswa kelas V SD di Gugus III Kecamatan Tegallalang tahun pelajaran $2015 / 2016\left(F_{\text {hitung }}=4,400\right.$ dengan sig. $=$ 0,039). (4) Terdapat korelasi yang signifikan antara motivasi berprestasi dengan keterampilan proses sains pada siswa kelas $\mathrm{V}$ SD di Gugus III Kecamatan Tegallalang tahun pelajaran 2015/2016 $\left(\mathrm{r}_{\text {hitung }}=0,427\right.$ dengan sig. $=0,000)$. Dengan demikian, dapat disimpulkan bahwa terdapat pengaruh inkuiri terbimbing, gaya kognitif, dan motivasi berprestasi terhadap keterampilan proses sains siswa kelas V SD.

Bertolak dari hasil penelitian, dapat diajukan saran, yaitu (1) apabila guru mendesain pembelajaran yang bertujuan untuk meningkatkan keterampilan proses sains siswa sebaiknya guru menggunakan model pembelajaran inkuiri terbimbing dalam proses pembelajaran karena dengan model pembelajaran inkuiri terbimbing siswa akan dapat menemukan sendiri pengetahuan yang diharapkan melaluI bimbingan guru dalam proses pembelajaran. (2) Guru harus mendesain pembelajaran yang sesuai dengan gaya kognitif yang dimiliki oleh siswa 
sehingga siswa yang memiliki gaya kognitif reflektif dan siswa yang memiliki gaya kognitif impulsif dapat mengikuti proses pembelajaran dengan baik dan dapat memperoleh hasil yang baik pula. (3) Dalam mendesain pembelajaran guru harus memperhatikan model pembelajaran dan gaya kognitif yang dimiliki oleh siswa agar siswa dapat mengikuti proses pembelajaran dengan baik. (4) Dalam mendesain pembelajaran guru harus memperhatikan model pembelajaran dan tingkat motivasi berprestasi yang dimiliki oleh siswa agar siswa dapat mengikuti proses pembelajaran dengan baik. (5) Bagi peneliti lain yang berminat mengadakan penelitian lebih lanjut, agar menambah variabel terikat dan variabel kontrol yang hendak diteliti agar penelitian yang dilakukan lebih baik. (6) Peneliti lain yang berminat untuk melakukan penelitian lebih lanjut tentang pengaruh model inkuiri terbimbing, gaya kognitif dan motivasi berprestasi terhadap keterampilan proses sains agar menyesuaikan dengan permasalahan di lapangan dan tetap memperhatikan kendalakendala yang dialami dalam penelitian ini sehingga hasil penelitian yang diperoleh lebih baik dari penelitian yang telah dilakukan.

\section{DAFTAR RUJUKAN}

Dantes, N. 2014. "Kurikulum 2013 sebagai Kurikulum Berbasis Afeksi". Makalah disajikan dalam Seminar Keluarga Alumni Jurusan PGSD FIF Undiksha dengan Tema "Melalui Seminar Kurikulum 2013 Kita Tingkatkan Profesionalisme Guru”. Universitas Pendidikan Ganesha, 6 Maret 2014.

Emmanuel, A. O. et al. 2014. "Achievement Motivation, Academic Self-Concept And Academic Achievement Among High School Students". European Journal of Research and Reflection in Educational Sciences, Volume 2, Nomor 2 (hlm. 24-37).

Ergul, R. et al. 2011. "The Effects Of InquiryBased Science Teaching On Elementary School Students' Science Process Skills And Science Attitudes". Bulgarian Journal of Science and Education Policy (BJSEP). , Volume 5, Nomor 1 (hlm. 48-68).
Hamalik, O. 2012. Kurikulum dan Pembelajaran. Jakarta: Bumi Aksara.

Kemenkopmk, 2015. "Indonesia Peringkat ke57 EDI dari 115 Negara Tahun 2014". Tersedia pada www.kemenkopmk.go.id/artikel/indones ia-peringkat-ke-57-edi-dari-115-negaratahun-2014 (diakses tanggal 19 Nopember 2015).

Khodadady, E. et al. 2012. "Cognitive Styles and Performance on Schemabased Cloze Multiple Choice Item Tests: A Fairness Issue". Journal of Language Teaching and Research, Vol. 3, No. 4. Tersedia pada http://ojs.academypublisher.com/index.p hp/jltr/article/view/jltr0304806813/5012 (diakses tanggal 16 Nopember 2015).

Kurniasih, I. \& Berlin, S. 2015. Ragam Pengembangan Model Pembelajaran Untuk Peningkatan Profesionalitas Guru. Jakarta: Kata Pena.

Matthew, B. M. \& Igharo, O. K. 2013. "A Study On The Effects Of Guided Inquiry Teaching Method On Students Achievement In Logic". International Researchers, Volume 2, Nomor 1 (hlm. 135-140).

Pandaeyani, P. H. D. 2012. "Implementasi Model Pembelajaran Inkuiri Terbimbing untuk Meningkatkan Hasil Belajar dan Keterampilan Proses IPA Siswa Kelas V Semester Ganjil SD Negeri 2 Dencarik Kecamatan Banjar Kabupaten Buleleng Tahun Pelajaran 2012/2013". Skripsi (tidak diterbitkan). Jurusan Pendidikan Guru Sekolah Dasar, FIP Undiksha.

Suarni, N. K. 2004. "Meningkatkan Motivasi Berprestasi Siswa Sekolah Mengah Umum di Bali dengan Strategi Pengelolaan Diri Model Yates". Disertasi (tidak diterbitkan). Universitas Gadjah Mada.

Suastra, I W. 2009. Pembelajaran Sains Terkini: Mendekatkan Siswa dengan Lingkungan Alamiah dan Sosial Budaya. Singaraja: Universitas Pendidikan Ganesha. 
Susanto, A. 2013. Teori Belajar dan Pembelajaran di Sekolah Dasar. Jakarta: Kencana Prenadamedia Group.

Warli. 2010. Instrumen Gaya Kognitif Refletif dan Impulsif: Matching Familiar Figures Test (MFFT). Test (tidak diterbitkan). Program Pascasarjana, Program Pendidikan Matematika, UNESA.

Widadah, S. 2013. "Profil Metakognisi Siswa Dalam Menyelesaikan Soal Sistem Persamaan Linear Dua Variabel Berdasarkan Gaya Kognitif". Jurnal Pendidikan Matematika. Volume1, Nomo1 (hlm. 13-24). 